\title{
Pendekatan Partisipatif Dalam Memberdayakan Pemasaran Online UMKM di Kampung Krupuk Sukolilo Surabaya
}

\author{
Moch Djauhari, Rama Abi, Andini Putri, Yusuf A, Muclis Adi, Rona Ayu \\ Sekolah Tinggi Ilmu Komunikasi Almamater Wartawan Surabaya . \\ Jalan Nginden Intan Timur I / 18 Surabaya \\ Email: djauhari.stikosa@gmail.com
}

\begin{abstract}
Kenjeran residents in the kerupuk sukolilo village, Surabaya city work as fishermen and sell their produce in the form of fish crackers, sea cucumber crackers, squid crackers, and lorjuk crackers. Product sales were made through 75 shops in a traditional manner because the merchants did not understand online sales. The purpose of this activity is to invite Kenjeran processed marine cracker traders to take advantage of technology and understand online sales of processed seafood cracker products so that they can help speed up trade turnover. The method used is a participatory approach with the consideration that the active involvement of community service research subjects is an important factor for determining programs that are targeted, practically oriented, empowering and sustainable.

These results indicate that the participatory model in the introduction and application of technology is very effective and right on target for marine processed cracker village residents, online sales can be done by cracker village residents without leaving traditional sales.
\end{abstract}

Keywords: cracker village, online marketing, participatory method, empowerment

\begin{abstract}
Abstrak
Sebagian warga Kenjeran di kampung kerupuk sukolilo kota Surabaya berprofesi sebagai nelayan dan menjual hasilnya berupa kerupuk ikan, kerupuk teripang, kerupuk cumi, dan kerupuk lorjuk. Penjualan produk dilakukan melalui 75 toko secara tradional karena para pedagang tidak memahami penjualan secara online. Tujuan dari kegiatan ini adalah mengajak pedagang kerupuk olahan laut Kenjeran dapat memanfaatkan teknologi dan memahamai penjualan secara online untuk produk kerupuk olahan hasil laut sehingga dapat membantu mempercepat perputaran dagang. Metode yang dipakai adalah pendekatan partisipatif dengan pertimbangan bahwa pelibatan aktif subyek penelitian pengabdian merupakan faktor yang penting untuk menentukan program yang tepat sasaran, berorientasi praktis, pemberdayaaan dan berkelanjutan.

Hasil ini menunjukan bahwa model partisipatif dalam pengenalan dan penerapan teknologi untuk yang dilakukan sangat efektif dan tepat sasaran pada warga kampung kerupuk olahan laut, penjualan secara online dmampu dilakukan oleh warga kampung kerupuk tanpa meninggalkan penjualan secara tradisional.
\end{abstract}

Kata Kunci : kampung kerupuk, pemasaran online, metode partisipatif, pemberdayaan

\section{PENDAHULUAN}

Konsep pemasaran adalah konsep totalitas di bidang pemasaran, yang mencakup sebelum barang diproduksi hingga diperdagangkan dan layanan pasca penjualan yang akhirnya dapat memuaskan konsumen. Merencanakan dan melaksanakan pemasaran merupakan faktor penting untuk mencapai target pemasaran. Pentingnya keberadaan usaha kecil untuk 
menciptakan stabilitas ekonomi para pelaku UMKM melalui peningkatan produk yang terjual melalui pemasaran, namun karena tingkat pemasarannya yang masih bersifat tradisional maka menyebabkan perputaran penjualan produk menjadi rendah. Pemasaran produk pada UMKM yang rendah dikarenakan kompetensi sumber daya manusia para pelaku UMKM tidak memahami teknologi yang dapat digunakan untuk memasarkan produk melalui media online, para pelaku UMKM memerlukan pembinaan dan pendampingan dari berbagai pihak. Salah satu UMKM di Kota Surabaya yang mempunyai potensi untuk di kembangkan dan memerlukan pendampingan adalah UMKM krupuk, karena kerupuk merupakan salah satu makanan ringan yang banyak diburu para konsumen. Rasanya yang gurih dan teksturnya yang sangat renyah, menjadikan kerupuk sebagai salah satu makanan ringan sebagai pelengkap aneka hidangan yang banyak dicari para konsumen. Sebagian masyarakat Indonesia merasa ada yang kurang bila makan tanpa memakan kerupuk. Peluang inilah yang di lirik oleh pemerintah Kota Surabaya untuk mengembangkan sentra produksi kerupuk sebagai alternatif peluang usaha yang cukup menjanjikan bagi para pelakunya.

Salah satu sentral krupuk yang dikembangkan oleh Pemerintah Kota Surabaya adalah daerah Kenjeran, karena daerah ini dekat dengan laut sehinga setiap harinya ada berbagai macam hasil laut seperti ikan,udang,kerang, terung dan lain-lainya yang bisa di dapatkan sebagai bahan pembuat krupuk udang, krupuk kerang dan jenis krupuk lainnya. Namun pada era yang berkembang ini, pemasaran yang dilakukan oleh UMKM tersebut masih menggunakan cara lama yaitu pemasaran mulut ke mulut (offline). Cara pemasaran lama ini sudah berjalan bertahun-tahun di kampung krupuk. Sebagian penjual merasa tidak ada waktu untuk memperdagangan secara online.

Berdasarkan analisa situasi diatas maka 75 pelaku UMKM kerupuk hasil olahan ikan yang ada di kampung kerupuk sukolilo perlu mendapatkan pendampingan dan pelatihan secara praktis dan tepat guna untuk membantu peningkatan penjualan produk baik dari penjualan secara tradisional di tambah dengan penjualan online.

\section{Pengertian partisipasi}

Verhangen (1979) dalam Mardikanto (2003) menyatakan bahwa, partisipasi merupakan suatu bentuk khusus dari interaksi dan komunikasi yang berkaitan dengan pembagian: kewenangan, tanggung jawab, dan manfaat. Theodorson dalam Mardikanto (1994) mengemukakan bahwa dalam pengertian sehari-hari, partisipasi merupakan keikutsertaan atau keterlibatan seseorang (individu atau warga masyarakat) dalam suatu kegiatan tertentu. Keikutsertaan atau keterlibatan yang dimaksud di sini bukanlah bersifat pasif tetapi secara aktif ditujukan oleh yang bersangkutan. Oleh karena itu, partisipasi akan lebih tepat diartikan sebagi keikutsertaan seseorang didalam suatu kelompok sosial untuk mengambil bagian dalam kegiatan masyarakatnya, di luar pekerjaan atau profesinya sendiri.Faktor-faktor yang mempengaruhi terhadap tumbuh dan berkembangnya partisipasi dapat didekati dengan beragam pendekatan disiplin keilmuan.

Partisipasi masyarakat merutut Hetifah Sj. Soemarto (2003) adalah proses ketika warga sebagai individu maupun kelompok sosial dan organisasi, mengambil peran serta ikut mempengaruhi proses perencanaan, pelaksanaan, dan pemantauan kebijakan kebijakan yang langsung mempengaruhi kehiduapan mereka. Conyers (1991) menyebutkan tiga alasan mengapa partisipasi masyarakat mempunyai sifat sangat penting. Pertama partispasi masyarakat merupakan suatu alat guna memperoleh informasi mengenai kondisi, kebutuhan, 
dan sikap masyarakata, tanpa kehadirannya program pembangunan serta proyek-proyek akan gagal, alasan kedua adalah bahwa masyarakat akan lebih mempercayai proyek atau program pembangunan jika merasa dilibatkan dalam proses persiapan dan perencanaannya, karena mereka akan mengetahui seluk beluk proyek tersebut dan akan mempunyai rasa memiliki terhadap poyek tersebut. Alasan ketiga yang mendorong adanya partisiapsi umum di banyak negara karena timbul anggapan bahwa merupakan suatu hak demokrasi bila masyarakat dilibatkan dalam pembangunan masyarakat mereka sendiri. Hal ini selaras dengan konsep mancetered development yaitu pembangunan yang diarahkan demi perbaikan nasib manusia.

\section{Pemberdayaan Masyarakat}

Pemberdayaan masyarakat dapat diartikan sebagai suatu proses yang membangun manusia atau masyarakat melalui pengembangan kemampuan masyarakat, perubahan perilaku masyarakat, dan pengorganisasian masyarakat. Ada 3 tujuan utama dalam pemberdayaan masyarakat yaitu mengembangkan kemampuan masyarakat, mengubah perilaku masyarakat, dan mengorganisir diri masyarakat. Kemampuan masyarakat yang dapat dikembangkan tentunya banyak sekali seperti kemampuan untuk berusaha, kemampuan untuk mencari informasi, kemampuan untuk mengelola kegiatan, kemampuan dalam pertanian dan masih banyak lagi sesuai dengan kebutuhan atau permasalahan yang dihadapi oleh masyarakat.

Perilaku masyarakat yang perlu diubah tentunya perilaku yang merugikan masyarakat atau yang menghambat peningkatan kesejahteraan masyarakat. Contoh yang kita temui dimasyarakat seperti, anak tidak boleh sekolah, yang membicarakan rencana pembangunan desa hanya kaum laki-laki saja, dan masih banyak lagi yang dapat kita temui dimasyarakat. Pengorganisasian masyarakat dapat dijelaskan sebagai suatu upaya masyarakat untuk saling mengatur dalam mengelola kegiatan atau program yang mereka kembangkan. Disini masyarakat dapat membentuk panitia kerja, melakukan pembagian tugas, saling mengawasi, merencanakan kegiatan, dan lain-lain.

\section{METODE PELAKSANAAN}

Kegiatan Pengabdian Kepada Masyarakat (PKM) ini menggunakan pendekatan partisipatif dengan pertimbangan bahwa pelibatan aktif subyek penelitian merupakan faktor yang penting untuk menentukan program yang tepat sasaran, berorientasi praktis, pemberdayaaan dan berkelanjutan (Djohani dalam Poerwandari, 2005).

Mahasiswa Stikosa-AWS ikut berpartisipasi melakukan penyuluhan tentang pemasaran online kepada pelaku UMKM Kampung Krupuk warga kampung Sukolilo, Surabaya. Pengambilan data dilakukan melalui observasi dan wawancara. Data yang diperoleh berupa data primer dan data sekunder. Data primer diperoleh melalui wawancara langsung dari ketua koordinator UMKM Kampung Krupuk.

Data sekunder diperoleh dari pelaku UMKM yang tergabung. Metode wawancara dilakukan dengan cara bertanya langsung dengan Ketua UMKM Kampung krupuk maupun dengan pedagang pada UMKM yang ada. Sedangkan metode observasi dilakukan dengan cara mengamati langsung proses pemahaman dan penggunaan teknologi oleh para pelaku UMKM setelah dilakukan penyuluhan oleh mahasiswa Stikosa-AWS.

Metode kegiatan ini berupa pelatihan kepada pelaku UMKM kampung krupuk Sukolilo Kenjeran Surabaya. Setelah diberi pelatihan, selanjutnya mereka dibimbing untuk menerapkan hasil pelatihan dalam rangka memanfaatkan media sosial dan market place (shoope, lazzada, tokopedia dan lainnya) dalam pemasaran. 
Berikut ini adalah tahapan pelatihan yang dilakukan:

1.Tahap Persiapan, yang dilakukan meliputi :

a.Survei.

b.Pemantapan dan penentuan lokasi dan sasaran.

c.Penyusunan bahan/materi pelatihan, yang meliputi: makalah dan modul untuk kegiatan pelatihan.

2. Tahap Pelaksanaan Pelatihan

Tahap ini menjelaskan tentang pentingnya bagi pelaku usaha untuk mengetahui aplikasi media sosial dan market place dan mengaplikasikannya di dunia usaha. Selanjutnya, sesi pelatihan yang menitik beratkan pada kemampuan membuat bahan pemasaran dengan menggunakan aplikasi media sosial dan market place. Pemberian pelatihan ini dilakukan dengan teknik simulasi agar para pelaku usaha mendapatkan pengalaman langsung sekaligus pengayaan informasi.

\section{Metode Pelatihan}

Untuk melaksanakan kegiatan tersebut digunakan beberapa metode pelatihan, yaitu:

a.Metode Ceramah

Metode ceramah dipilih untuk memberikan penjelasan bagi pelaku UMKM kampung krupuk untuk mengetahui aplikasi media sosial dan market place dan mengaplikasikannya untuk pembelajaran di dunia usaha.

b.Metode Tanya Jawab

Metode tanya jawab sangat penting bagi para pelaku UMKM kampung krupuk, baik di saat menerima penjelasan tentang topik yang dibahas serta saat mempraktekkannya

c.Metode Simulasi

Metode simulasi ini sangat penting diberikan kepada para pelaku UMKM kampung krupuk pelatihan untuk memberikan kesempatan mempraktekkan materi pelatihan yang diperoleh.

Evaluasi proses dan hasil (pencapaian tujuan pelatihan) dilakukan dengan angket tanya jawab, dan observasi. Sedangkan evaluasi aspek penyelenggaraan pelatihan dilakukan dengan pemberian wawancara keberhasilan dalam pelaksanaan pelatihan media pembelajaran online dengan menggunakan aplikasi media sosial dan market place untuk pelaku UMKM kampung krupuk ada 2 metode, yaitu:.

1. Evaluasi selama proses pelatihan

Evaluasi saat pelaksanaan pelatihan meliputi, keterlibatan dan kemampuan pelaku UMKM kampung krupuk setiap tahap pelatihan. Pada tahap akhir, peserta diharapkan dapat memanfaatkan aplikasi media sosial dan market place untuk membuat media pemasaran.

2. Evaluasi Pasca Pelatihan

Keberhasilan kegiatan pengabdian masyarakat ini akan dievaluasi berdasarkan taraf penyelesaian materi pelatihan, dan Tim Pengabdian akan melakukan evaluasi dengan mengamati dan memeriksa hasil desain pemanfaatan aplikasi media sosial dan market place dalam pembuatan media pemasaran. 
Moch Djauhari dkk: Pendekatan Partisipatif Dalam Memberdayakan Pemasaran Online UMKM diKampung Krupuk Sukolilo Surabaya

\section{HASIL DAN PEMBAHASAN}

\subsection{Potensi Sumber Daya Ekonomi dan Manusia}

Hasil survey di kampung krupuk Sukolilo Kenjeran, Kota Surabaya ada 75 toko yang menjual krupuk hasil olahan laut yang sudah ada dan terus berkembang. Sementara itu hasil wawancara menunjukkan bahwa sumber daya manusia (pelaku UMKM kerupuk) menunjukkan sisi kelemahan yakni :

1.Kurang pengetahuan tentang teknologi promosi dan pemasaran

2.Sebagian masih belum memiliki gadget yang memadai untuk melakukan promosi dan pemasaran online

Tetapi pengalaman melakukan wawancara dengan para pelaku UMKM kerupuk, satu poin yang dicatat bahwa mereka memiliki KEMAUAN UNTUK BELAJAR MAJU, hanya saat itu tidak tahu bagaimana cara untuk belajar.

Maka diperlukan satu bentuk pemberdayaan yang bersifat partisipatif kepada para pelaku UMKM kerupuk hasil olahan laut yang diintegrasikan kedalam program peningkatan pemahaman teknologi promosi dan pemasaran online berbasis kampung kerupuk Sukolilo Kenjeran.

\subsection{Pemahaman Pelaku UMKM Tentang Pemberdayaan}

Beberapa poin yang dapat di catat selama berinteraksi wawancara adalah:

Sepanjang yang dapat dilihat selama proses wawancara, sejumlah hal yang dapat dicatat:

1.Pelaku UMKM kerupuk olahan hasil ikan tahu tentang dan penting-nya program pemberdayaan, apakah dari pemerintah atau CSR pihak swasta.

2.Pelaku UMKM kerupuk olahan hasil ikan masih memiliki kepedulian yang rendah tentang pemberdayaan produk melalui pemasaran, baik secara tradisional dan online.

Kunci dari proses pemberdayaan untuk pelaku UMKM kerupuk hasil olahan laut adalah bersifat partisipatif. Desain pemberdayaan yang bersifat partisipatif yakni peningkatan pengetahuan teknologi dan penerapan pada media sosial dan market place

Pemberdayaan pelaku UMKM kerupuk hasil olahan laut, memiliki makna bagaimana agar pelaku UMKM kerupuk hasil olahan laut ini menjadi produktif untuk memasarkan produknya selain tradisional juga melalui online yang lebih luas area-nya, untuk menambah kenaikan ekonomi serta perputaran produknya. Pendekatannya bukan dalam bentuk memberikan dana atau membeli produk dalam jumlah besar tetapi dengan memberdayakan kemampuan diri untuk produktif lebih dalam penjualan melalui media sosial dan market place.

Kelompok masyarakat kampung kerupuk hasil olahan laut tersebut merupakan kelompok usaha ekonomi yang penting dalam perekonomian Kota Surabaya. Hal ini disebabkan, usaha kecil menengah merupakan sektor usaha yang memiliki jumlah terbesar dengan daya serap angkatan kerja yang signifikan. Peneliti pada pengabdian masyarakat memahami bahwa kampung kerupuk hasil olahan laut adalah program peningkatan penghidupan masyarakat berbasis komunitas.

Pendekatan partisipatif yang sesuai bagi masyarakat pelaku UMKM kampung kerupuk hasil olahan laut, sebaiknya :

1.Aspek yang menjadi sasaran :

a. Pengetahuan tentang promosi dan pemasaran dari tradisional menuju online

b. Program pelatihan penerapan teknologi secara berkelanjutan

2.Hal yang harus ditumbuhkan dari pelaku UMKM kerupuk hasil olahan laut adalah :

a.Motivasi kuat untuk terus berkembang dalam bidang pemasaran online 
b.Bertanggung jawab ikut membantu dan saling menguatkan kepada sesama pelaku UMKM kerupuk hasil olahan melalui promosi dan pemasaran online

\subsection{Pendekatan Partisipatif Tahap Pendahuluan}

Dilakukan dua langkah identifikasi terhadap aspek internal dan eksternal dari pelaku UMKM kerupuk hasil olahan laut. Aspek internal mencakup kualitas produk kerupuk dan kemampuan manajerial dalam melakukan promosi dan pemasaran. Tahap tahap ini harus dilakukan pengamatan langsung secara seksama, tidak mengandalkan data sekunder atau wawancara saja. Aspek eksternal mencakup kemampuan pelaku UMKM kerupuk hasil olahan laut dalam mencari akses kompetitor agar harga produk dapat bersaing. Selain itu juga dilihat akses kepada pasar, apakah pelaku UMKM kerupuk hasil olahan laut ini memang sudah memiliki akses kepada pasar online atau hanya mengandalkan pemasaran tradisional saja.

Setelah aspek internal dan eksternal teridentifikasi, dilakukan analisis kebutuhan nyata. Artinya dalam melihat secara nyata, apa sebenarnya kebutuhan bagi para pelaku UMKM kerupuk hasil olahan laut, apakah memang peningkatan keterampilan, peningkatan kemampuan manajerial, peningkatan akses kepada pasar, kemudahan memperoleh bahan baku, peningkatan promosi, introduksi teknologi.

\subsection{Pendekatan Partisipatif Tahap I}

Pada tahap pertama. Melakukan penyuluhan tentang manfaat berpromosi melalui media digital. Penyuluhan tentang manfaat berpromosi melalui media digital merupakan awal dari pelaksanaan pengabdian yang dilakukan. Selain itu, penyuluhan promosi pemasaran online ini bermanfaat untuk meningkatkan minat penjual terhadap promosi online. Penyuluhan yang digunakan adalah dengan cara melalui group Whatsapp mulai dari pengenalan sampai manfaat dalam berpromosi melalui media digital. Aplikasi yang digunakan untuk menjadi materi dalam penyuluhan adalah market place Shopee.

\subsection{Pendekatan Partisipatif Tahap II}

Pada tahap kedua. Membuat Akun e-comemmerce. Aktifitas penyuluhan tentang manfaat berpromosi melalui media digital ini mampu membuat pelaku UMKM kerupuk olahan hasil laut menjadi tertarik karena bisa membantu meningkatkan penjualan. Dalam tahapan ini, merupakan langkah untuk menunjukan kepada para pelaku UMKM kerupuk olahan hasil laut untuk melihat bagaimana cara pembuatan akun E-Comemmerce atau Shopee. Peneliti memberikan tata cara pembuatan akun Shopee melalui rekaman tahapan video yang akan di upload pada Youtube, setelah itu peneliti share ke grup Whatsapp yang terdiri dari beberapa pelaku UMKM kerupuk olahan hasil laut.

\subsection{Pendekatan Partisipatif Tahap III}

Pada tahap ketiga. Mengajarkan foto produk yang baik untuk diupload dalam e-commerce. Setelah pelaku UMKM kerupuk olahan hasil laut memiliki atau tahu cara mendaftar akun ecommerce, peneliti juga memberikan pelatihan online melalui youtube bagaimana pengambilan foto yang baik untuk makanan menggunakan handphone, dan hal ini untuk membantu pelaku UMKM kerupuk olahan hasil laut mampu menciptakan foto produk yang menarik, sehingga mampu menarik minat pembeli di Shopee. 
Moch Djauhari dkk: Pendekatan Partisipatif Dalam Memberdayakan Pemasaran Online UMKM diKampung Krupuk Sukolilo Surabaya

\subsection{Pendekatan Partisipatif Tahap IV}

Pada tahap ke-empat. Memberikan materi tentang bagaimana membuat caption produk yang menarik. Setelah pelaku UMKM kerupuk olahan hasil laut meng-upload foto produknya, kemudian peneliti membagikan tips dan trik untuk membuat caption yang menarik agar produknya menarik perhatian konsumen. Beberapa saran yang diberikan peneliti untuk membuat caption adalah memberikan informasi produk dengan lengkap, dengan menyertakan harga, ukuran, dan kemasan, sehingga calon pembeli mengetahui produk yang dijual dengan mudah. Kemudian penggunaan hashtag (\#) yang relevan dengan produk yang dijual oleh pelaku UMKM kerupuk olahan hasil laut. Dengan demikian penulisan caption ini dapat digunakan tidak hanya di market place namun diseluruh media sosial lain seperti facebook, instagram, dan lainnya.

\subsection{Pendekatan Partisipatif Tahap V}

Pada tahap kelima. Cara melakukan transaksi penjualan serta pengambilan dana melalui bank pribadi pelaku UMKM kerupuk olahan hasil laut dalam media digital atau e-commerce. Tahapan berikutnya adalah melakukan transaksi penjualan, seperti sebelumnya dalam pelatihan adalah menggunakan e-commerce shopee, saat ada orderan masuk akan ada notifikasi dari akun mereka yang dimana mereka harus mempacking barang mereka untuk di kirim ke pengiriman yang telah dipilih oleh pembeli. Setelah itu, dalam aplikasi tersebut memberikan informasi pada pelaku UMKM kerupuk olahan hasil laut harus sudah memiliki bank pribadi untuk menarik hasil penjulan mereka di shopee ataupun e-commerce lainnya.

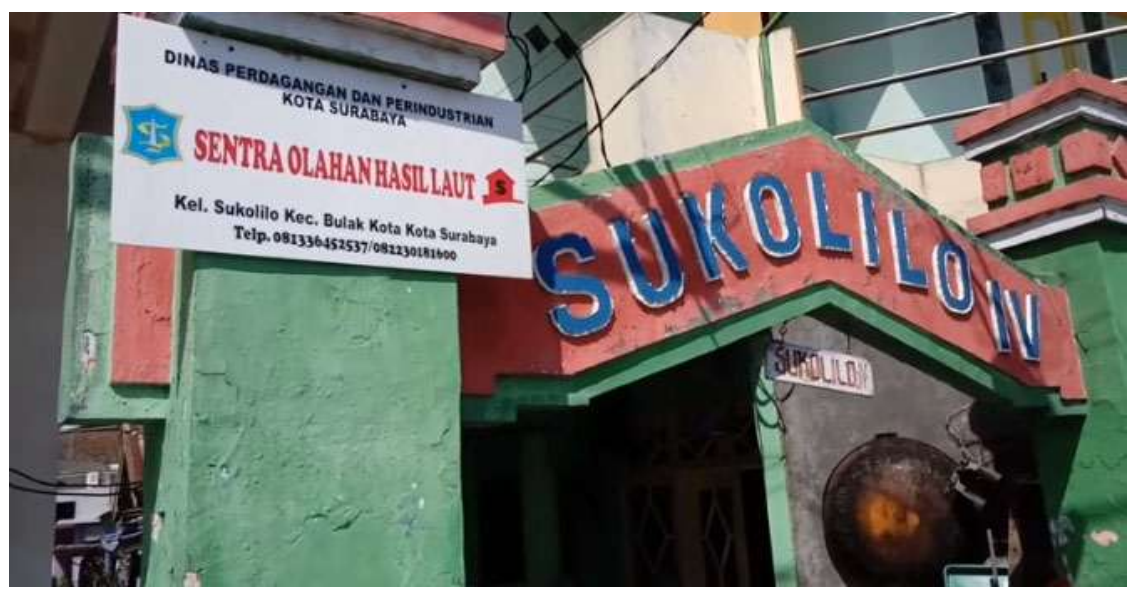

Gambar 1.Kampung Kerupuk Olahan Hasil Laut 


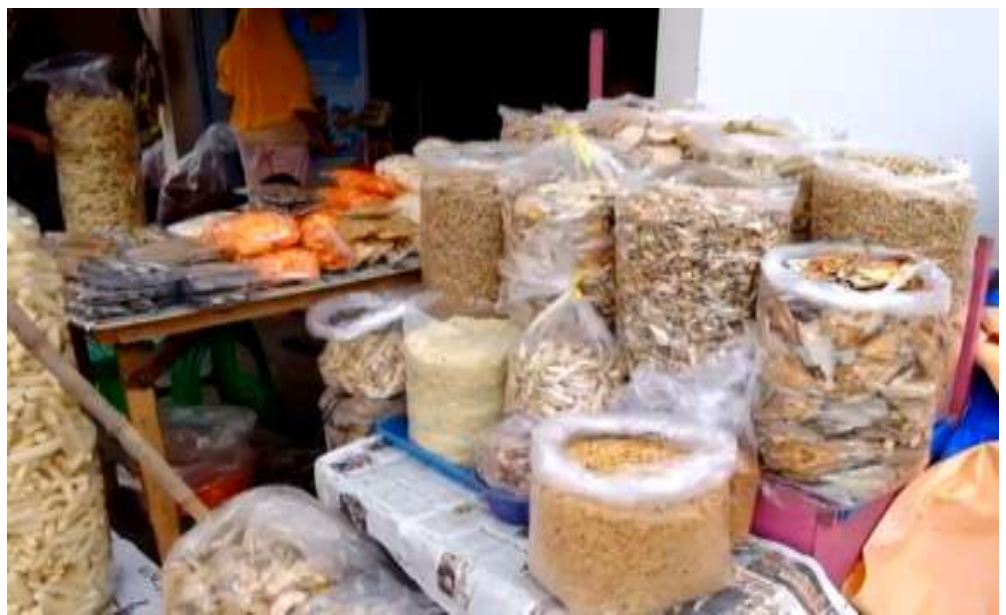

Gambar 2. Aneka Krupuk Olahan Hasil Laut

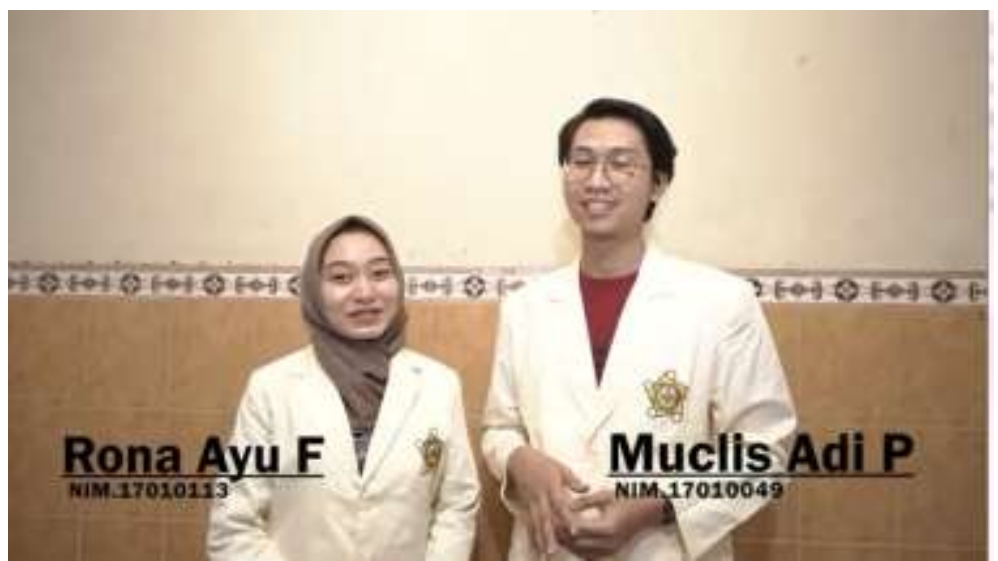

Gambar 3. Video Tutorial Lengkap Market Place (shopee)

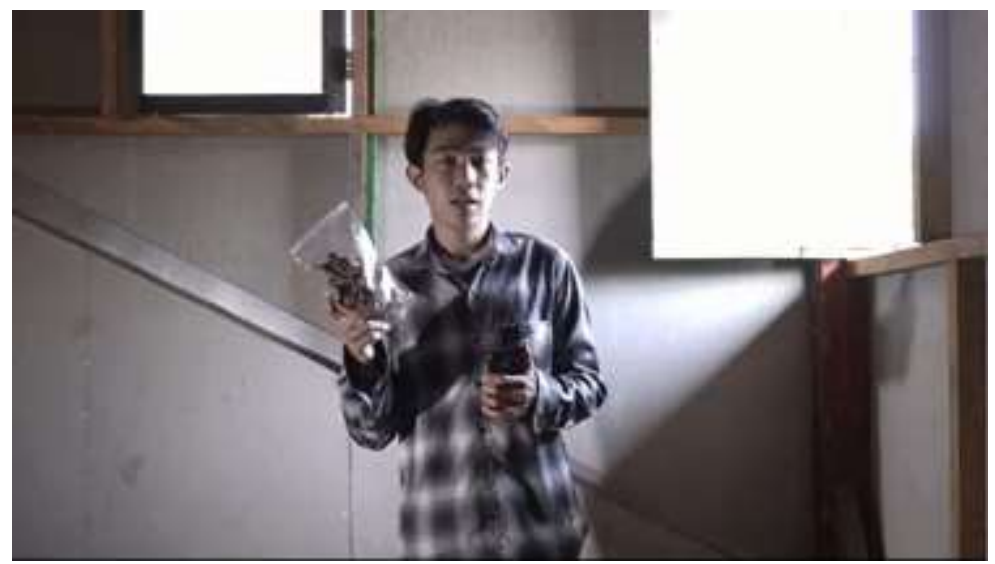

Gambar 4. Video Tutorial Lengkap Foto Produk 
Moch Djauhari dkk: Pendekatan Partisipatif Dalam Memberdayakan Pemasaran Online UMKM diKampung Krupuk Sukolilo Surabaya

\section{PENUTUP}

Sumber daya manusia pelaku UMKM kerupuk hasil olahan laut secara umum menunjukkan dua kelemahan yakni : (1)Kurang pengetahuan tentang pengemasan, promosi, pemasaran online (2) Belum memiliki wawasan dan akses terhadap teknologi yang baik. Diperlukan perhatian pemberdayaan dari Pemerintah Kota Surabaya dan pihak swasta untuk membantu memfasilitasi teknologi yang berkelanjutan seperti koneksi internet dan pelatihan. Pendekatan partisipatif yang sesuai bagi pelaku UMKM kerupuk olahan hasil laut. Selama berlangsungnya penyuluhan dan pelatihan media digital atau online di kampung kerupuk Sukolilo, para pelaku UMKM kerupuk olahan hasil laut sangat antusias. Hal ini dikarenakan media digital mampu meningkatkan daya jual untuk membantu perekonomian pelaku UMKM kerupuk olahan hasil laut kampung Sukolilo.

\section{DAFTAR PUSTAKA}

A.Shimp, Terence (2003). Periklanan Promosi \& Aspek Tambahan Komunikasi Pemasaran Terpadu, Jilid I (edisi 5), Jakarta: Erlangga

Agus Purbathin Hadi, ,Revisi Mekanisme Dan Peningkatan Kualitas Perencanaan Desa Menuju Pembangunan Desa Yang Partisipatif Dan Berkelanjutan Di Era Otonomi Daerah, Program Studi Penyuluhan dan Komunikasi Pertanian Fakultas Pertanian Universitas Mataram

Analisis Multi Kriteria Sebagai Metode Pemilihan Suatu Alternatif Ruas Jalan di Propinsi Lampung, Rahayu Sulistyorini dan Dwi Herianto, Jurnal Rekayasa Vol. 14 No. 3, Desember 2010

Artiningtiyas, 2012, Analisis Tingkat Keberhasilan Pinjaman Bergulir PNPM Mandiri Perkotaan Berdasarkan Tingkat Konsumsi Masyarakat, Studi Kasus Kecamatan Petarukan, Kabupaten Pemalang, Fakultas Ekonomi, Universitas Indonesia, Jakarta

Asmara, Lalu Hajar., 2001, Mencari Format Perencanaan Pembangunan yang Aspiratif Untuk Mendukung Implementasi Otonomi Daerah. Makalah diskusiinternal Bapeda Lombok Tengah tanggal 10 April 2001.

Bryant, Coralie and White, G, Louise, 1989 Manajemen Pembangunan Untuk Negara Berkembang, pengantar Dorodjatun Kuntjoro-jakti, Jakarta; LP3ES.

Colletta, Nat J dan Umar Kayam. 1987. Kebudayaan dan Pembangunan. Yayasan OborIndonesia. Pp.333.

Creeber,G.and Martin, R., (ed).,2009. Digital Cultures: Understanding New Media, Berkshire-England: Open University Press

Rowley, J., 2008, 'Understanding digital content marketing', Journal of Marketing Management, Volume 24, 2008 - Issue 5-6, pp. 517-540. 